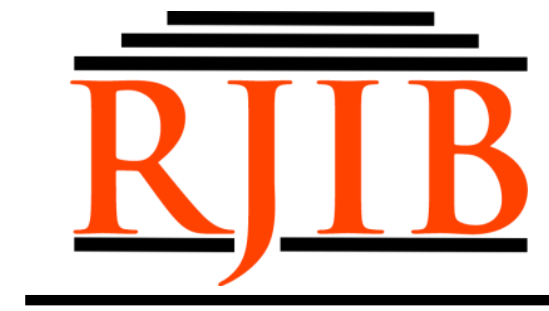

RETORIKA: Jurnal Ilmu Bahasa

Vol. 7, No. 2 October 2021, Page 157-165

P-ISSN: 2406-9019

E-ISSN: 2443-0668

Available Online at https://ejournal.warmadewa.ac.id/index.php/jret

\title{
Sociological Analysis of the Important Characters in Kevin Kwan's Crazy Rich Asians
}

\author{
Gusti Ayu Made Rai Suarniti \\ Fakultas Sastra, Universitas Warmadewa \\ raisuarniti78@gmail.com
}

Published: $15 / 10 / 2021$

How to cite (in APA style):

Suarniti, G. A. M. R. (2021). Sociological Analysis of the Important Characters in Kevin Kwan's Crazy Rich Asians. Retorika: Jurnal Ilmu Bahasa, 7(2), 157-165. doi: https://doi.org/10.22225/jr.7.2.3037.157-165

\begin{abstract}
This research is about the sociological problems of five important characters in Kevin Kwan's Crazy Rich Asian. Rachel Chu is the main character in this story comes from the middle class society. She has a relationships with Nicholas Young who comes from the upper class society. They face a lot of problems especially from Nicholas's family who doesn't agree with their relationships. Different society influences the character of someone. That's why this research is aimed to find out the types of social class and the influence of social class on the character that showed in the story. The data were collected by reading the novel thoroughly then using the note-taking technique before being identified based on the topic. The collected data were descriptively analyzed by using qualitative-descriptive method to classify the types of social class and the influence of social class on the character that found in this novel. Based on the result of the research, it is found that there are three kinds of social class in Kevin Kwan's Crazy Rich Asian, those are: Upper class, Middle class and Working class. Rachel Chu who comes from the middle class society has a simple personality. She prefers to save her money for food though she is a lecturer in university rather than her boyfriend, Nicholas Young who comes from the worthy family. Nick's family are also live glamor in Singapore. They spend a lot of money for fashion and jewelry. It much different with Rachel's mom (Kerry Chu) who originally comes from working or lower class society. She fulfills her daughter alone and becomes a single parent because she has divorced with her husband when Rachel still child. This condition make Eleanor Young doesn't agree with the relationships however the power of love between Nick and Rachel defeated everything. Finally, they become a couple.
\end{abstract}

Keywords: Important Characters, Social Class

\section{INTRODUCTION}

Literature is a valuable beautiful writing. It is an art and creative work of social institution, literary work states about real life which happens in a society. Literature is a mirror of society in the era. We imagined the situation of the society through reading the works of literary. (Wellek \& Warren, 1956) stated literature as the one which represents a social a social reality even though the natural world and the inner of the subjective world of the individual have also been object of literary imitation. The social reality that the literature represents in the social reality which the people or the literary writer himself experiences in their or his life (Wellek \& Warren, 1956). Literature is commonly divided into prose fiction, poetry and drama. According to its genre, prose fiction can be devided into three. Those are short story, novellas and novel. (Di Yanni, 2001) stated that, the short novels sometimes called novellas, shares the 
characteristics with both of novel and short story.

Novel is a piece of literary which attempts to describe the universe in which we live and try to give a special value. So, we can learn about the world we live in as well. Novel is also principally have a structure. The structure of this fictional work are filled by two fundamental components. One of the components is intrinsic aspect that can be divided into plot, setting, character, etc. Plot is the author's arrangement of His events in the story . it is the movement structure in fiction. Story must move from beginning, middle to the end (Kenney, 1966). Setting reveals to us the where and when of events. It includes several closely related of a work of fiction. Those are setting of physical world, setting of time, setting of social environment and setting of atmosphere (Griffith, 2006). Character is considered as the potential element of fictional work especially in novel. Main character often identified as a major character. According to (Reaske, 1976), a major character is generally present during the substantial portion of book and his involved in the main plot. Main character is inherently important and we take a long, a hard book at Him in order to understand and author's meaning. Characters can actually be seen from many angles such as his/her function, role, characterizations and etc. To understand the character, it is necessary to understand the aspects of physiology, psychology, and sociology of the character itself.

The sociology of literature emphasizes literature as an important tool to convey a message to society about the reality of those around them. It is in line with (Sari \& Gaho, 2020), that language on literature can not be separated from a society. Literary works become the material to study the social life of a society. There is a close connection between literature and social life, because the social function of literature is how it involves itself in the midst of social life. Literary views its relationship with reality, the extent to which literary works that reflects the reality. (Swingewood, 1972) stated that literature as a complement in understanding society. The sociologist has the distinctive ways of examining human interactions. Sociology is the systematic study of social behavior and human groups. It focuses primarily on the influences of social relationships upon people's attitude and behavior and on how societies are established and changed (Schaefer, 1986). Therefore, an outline of this approach is that tells the various problems of human life especially the society. (Giddens \& Griffiths, 2006) stated that sociology is the scientific study of human social life, groups, and societies. Human is social creatures that cannot live alone, that is why, they need to get along with society that will naturally cooperates each other. Furthermore, (Smelser, 1981) stated that sociology is a scientific study of society and social relations among human beings. Sociology is science of interaction among people and the effect of this interaction on human behavior. The problems of sociology also can be seen from perspective of Marxist. According to (Tyson, 2006), the differences in socioeconomic class by dividing the people into two. They are the haves and the have nots.

One of the various problems in society is the problem of social class among community. Social class is differentiation in population and society makes classes in stages (hierarchy) where class differences occur based on society such as economy status. It can be seen from rich or poor person, education and lifestyle. (Jones, 2001) stated that class is the concept that has several contextual meanings. Class may be defined in terms of simple gradation based on material conditions. The sociological problems of social class are mostly occurs found in the work of literature such as in Kevin Kwan's Crazy Rich Asians. This social problems are usually illustrates about property as be seen from the glamor lifestyle of the upper class, gender, discrimination between the upper class society towards the middle class society and the lower or working class. Social class is differentiation in population or society which makes classes in stages (hierarchy) where class differences occur based on society such as economy status. In Crazy Rich Asians (2013), Kevin Kwan writes about social classes among people in Singapore.

\section{METHODS}

The data source is taken from "Crazy Rich Asians" (2013) by Kevin Kwan. Besides that, the writer chooses this novel because this novel is best-selling and the characters in this novel are full of hope, romantic, funny, thrilling and tragic in life and love. 
The method that are used in collecting the data are library research and observation method. The working procedure of the library research can be divided into several steps. The first step is reading Kevin Kwan's Crazy Rich Asians repeatedly and intensively in order to understand and comprehend the content of the story. Meanwhile the observation method is used for getting more understanding of the story by watching the film of Kevin Kwan's Crazy Rich Asians for several times. Finally, the collecting data is conducted finding out and underlining the specific statement that related to some types of social class and the influences of social class towards the important characters in of Kevin Kwan's Crazy Rich Asians.

The method and technique that are used in analyzing the data is qualitative - descriptive method by giving the description and explanation after collecting the data and the concepts. the data are furthermore analyzed based on the theoretical concepts themselves. The data are analyzed based on theory of literature about three dimensions of characterizations. Those are physiological aspect, psychological aspect and sociological aspect (Egri, 1946). By this characterizations of the important characters, furthermore, the problems are related to social class are found in of Kevin Kwan's Crazy Rich Asians. Moreover, the data is analyzed based on the theory of sociology about the particular social position within a class stratification system. Those are; lower class, working class, middle class and upper class or other such class designation (Kricken in (Ritzer \& Ryan, 2011)). All of the data in this research are presented in informal technique by using language that is easy to be understood.

\section{RESULT AND DISCUSSION}

Social class is differentiation in population or society makes classes in stages (hierarchy) where class differences occur based on society such as social and economy status. Class may be defined in terms of simple gradations based on material conditions. The analysis of Social class in Kwan's Crazy Rich Asians can be divided into three parts such as: Upper class, Middle class and Working class. The analysis can be explained from the quotation in the story of Kwan's Crazy Rich Asians. There are some kinds of social class and the analysis can be explained as follows:

\section{Upper Class}

The upper class in modern society is the social class composed of people who hold the highest social status. In this class, there are three members in this category they are: Nicholas Young, Eleanor Young and Astrid Leong. The analysis will be seen from education, occupation, wealth, family background and lifestyle.

\section{- Nicholas Young}

Nicholas Young is a 32 years old handsome man, Nick graduated from Oxford. He takes double-majored in history and law. Then, he is a professor in the history department and he is also the faculty adviser to the History Organization. He has the most seductive, slightly British accent. The analysis can be explained by the following quotation:

"He's just back from Oxford. Doublemajored in history and law," (Kwan, 2013: 17)

"No, no he's the brilliant new prof in the history department. He's also the faculty adviser to the History Organization."

"He has the most seductive, slightly British accent and he's a terrific dresser." (Kwan, 2013: 88)

Nicholas Young is a rich man in Singapore. He is the only 'Young' who still leaves in the line and will be the only heir. Nick doesn't realize how rich his family is. Though he comes from a worthy family, he still seeks his own income. The analysis can be explained by the following quotation:

"Yes, that's it. YOUNG. Now, out of your entire family, are there any other male cousins with this surname?"

"My point exactly. Besides your father, you are the only Young left in the line. You are the heir apparent," (Kwan, 2013: 148)

"And I have a private income that's not too shabby, mainly from stocks left to me by my grandfather." (Kwan, 2013: 451)

During his time as a lecturer. In New York, he is very simple person, he rented a comfortable studio apartment without a lot of luxury items and Nick dresses distinctively but 
casually. The analysis can be explained by the following quotation:

"Nick's lifestyle in New York could be described as modest, if not downright frugal. He rented a cozy alcove studio on Morton Street that didn't seem to contain anything of value aside from laptop, bike, and stacks of books. He dressed distinctively but casually" (Kwan, 2013: 214)

From the quotation above, Nicholas often travels by plane and uses the first-class ticket. Nick doesn't think of the cost because the most important thing for Nick is giving comfortable felling for Rachel. Nick lives at big house like a palace. He is not arrogant and during his time as a lecture, Nick is a simple person. He lives in studio apartment, it doesn't seem to contain anything of value aside from laptop, bike, and stacks of books.

\section{The Influences of Upper Class Toward Nicholas Young}

Social class influences Nicholas because he comes from a very wealthy family. Nick must maintain his attitude and he can't arbitrarily have a relationship to common peoples who are not from his level, especially about courtship and marriage. Everything is arranged by his mother. He must find a woman as same as his class and from a good family background, it makes Nicholas very sad and fells burdened because his girlfriend is a woman from different class.

\section{- Eleanor Young}

Eleanor Young is a 60 years old mother, she only has one son named Nicholas Young. Eleanor Young is much respected by her friends because she is the only child who speaks English rather than Chinese, she is a clever woman. The analysis can be explained by the following quotation:

"Carol still deferred to her. This was the way things had been since their childhood as neighbors growing up on Serangoon Road, mainly because, coming from a Chinese-speaking family, Carol had always felt inferior to Eleanor, who was bought up speaking English first.” (Kwan, 2013: 23)
Eleanor Young is very rich woman, she is respected by her friends for being Mrs. Philip Young. In her holiday time in London, she always rents a Lancaster Suite room at The Calthorpe hotel, this hotel is rented by important peoples and it is very expensive hotel. The analysis can be explained by the following quotation:

"Look! It says right here 'Mrs. Eleanor Young Lancaster Suite for four nights.' Do you not see this?" (Kwan, 2013: 5)

"The other also kowtowed to her, because even among these exceedingly well-married ladies, Eleanor had trumped them all by becoming Mrs. Philip Young." (Kwan, 2013: 24)

Eleanor Young has a very luxurious apartment with a prime position atop Cairnhill Road, the residence at One Cairnhill. The apartment are facility by expensive branded furniture and gold-plated lamps. The analysis can be explained by the following quotation:

"The space was made even more dramatic by a sunken oval pit in the center, with sleek Hermes-orange sofas perfectly contoured around both sides of the oval. From the ceiling, a spiral chandelier of sculptured gold and glass teardrops pirouetted down until it almost touched the oval driftwood coffee table. Rachel could hardly believe that Nick's parents lived in such a space," (Kwan, 2013: 317)

Eleanor's family background is very rich. She is from 'Sung' family, she comes from a very respectable family and she has got married to Philip Young. Her husband is an engineer who is very famous and worthy man. The analysis can be explained by the following quotation:

"Nick's father is an engineer. I think he works in Australia part of the years," Rachel offered. (Kwan, 2013: 142)

"I am a Sung I came from a respectable family, a rich family" (Kwan: 2013: 436)

From the quotation above, Eleanor Young comes from 'Sung' family who is very respectable and wealthy. She has got married to Philip Young he is an engineer and his family is very famous and worthy. Eleanor becomes 
one the generation who heir the wealthy and the lady of the house in Young's generations.

\section{The Influences of Upper Class Toward Eleanor Young \\ Social class influences Eleanor}

behaviors. She comes from the upper class and she always under estimates on peoples who are not at her level. She doesn't want her son to have a date or getting closer to peoples from different class as their family. Eleanor will find out the family's background of a woman who has close relationships to her son. She will look for their wealthy, jobs, wealth of her parents and how much influence does her family have. If Eleanor knew that the woman comes from a poor and unaffected family, she will keep her away from her son.

\section{- Astrid Leong}

Astrid Leong is a beautiful woman who grew up within Singapore's most elite milieu. Life follows the path which is starting at 6 years old. Astrid studies in a good school in Singapore and all of her education are determined by her family. The analysis can be explained by the following quotation:

"Beginning at age six, you were enrolled at Methodist Girls' School (MGS), Singapore Chinese Girls School (SCGS), the Convert of the Holy Infant Jesus (CHIJ). After school hours were consumed by a team of tutors preparing you for the avalanche of weekly exams (usually in classical Mandarin literature, multivariable calculus, and molecular biology), followed on the weekends by piano, violin, flute, ballet or riding and some sort of Christian Youth Fellowship activity.” (Kwan, 2013: 71)

After finishing her studies, Astrid Leong lives in Paris for the past few years and she doesn't have a job. She has got married and comes back to Singapore but she doesn't even seem like a true Singaporean. The analysis can be explained by the following quotation:

"They had nothing in common, except for the fact that they both knew Andy. She didn't have a job, she had been living

Paris for the past few years, so she was out of touch with Singapore. Hell, she didn't even seem like a true

Singaporean" (Kwan, 2013: 209)

Astrid Leong is a double heiress, there is greater wealth on his mother's side. Astrid Leong comes from affected family and very wealthy. It can be seen from her houses and the style of their livings. The analysis can be explained by the following quotation:

"You can't imagine how staggeringly rich these people are. The houses, the servants, the style in which they live. It makes Arnaults looks like peasants. What's more, I've been told that Astrid is a double heiress there's an even more enormous fortune on her mother's side." (Kwan, 2013: 44)

Astrid Leong comes from a very affected and wealthy family. Her father is a respected family that holds a monopoly over the palm oil industry. Then her mother is the eldest daughter of Sir James Young and the even more imperial Shang Su Yi. The analysis can be explained by the following quotation:

"Astrid's people have been wealthy for generations" (Kwan, 2013: 43)

"She was born into the uppermost echelon of Asian wealth a secretive. For starters, her father hailed from the Penang Leongs, a venerable straits Chinese family that held a monopoly over the palm oil industry. But adding even more oomph, her mother was the eldest daughter of Sir James Young and the even imperial Shang Su Yi" (Kwan, 2013: 46)

From the quotation above, Astrid Leong is a very influential and rich woman. Her father is very wealthy man and holding a monopoly on the palm oil industry. Her mother is the eldest daughter of the 'Young' family who is very wealthy.

\section{The Influences of Upper Class Toward Astrid Leong}

Social class influences the behavior of Astrid, she has to maintain 'Leong' family. She comes from a family that has a big influence for society. Astrid can't leave her luxurious life without shopping for some expensive jewelry and clothes. After getting married, she cannot 
shopping as she likes because her husband doesn't come from the rich family. She tried to hide her eyes on expensive jewelry and clothes immediately because she knows that the price of the clothes are more expensive than her husband's salary, so she has to respect her husband.

\section{Middle Class}

The middle class is a class of people in the middle of social hierarchy. The middle class is the broad group of people in contemporary society who fall socio-economically between the upper class and working class. People who being to this class are generally educated in college and have professional work.

\section{- Rachel Chu}

Rachel Chu is a 29-years-old woman, she has the principle to be a successful woman who gets the best education. She attended two of the top University in America, Stanford and Northwestern. Rachel is a professor of economics at New York University. The analysis can be explained by the following quotation:

"I'm told she's one of the up and coming professors in her field."

"Oh, economic development."

"Come on, Auntie Elle. Stanford is a great university for anywhere. I believe she also went to Northwestern for her master's. Rachel is very intelligent and capable, and completely down to earth" (Kwan, 2013: 61)

Rachel Chu is not from a wealthy family. She lives with a single mother who works hard for Rachel in order to get a good education. She may be an economist, but she is not materialistic. Rachel is a girl who doesn't like her stuff to be bought by someone else. She prefers to save and buy the stuff with her own money. The analysis can be explained by the following quotation:

"She may be an economist, but she's the least materialistic person I know." (Kwan, 2013, 149)

"I'm an economist, for crying out loud and if I'm going to be accused of being a gold digger" (Kwan, 2013: 451)

"I appreciate your generosity, but you just can't go around spending thousands of dollars on me. Now, I have money saved up for this trip and I will gladly pay for my own." (Kwan, 2013: 357)

Rachel is the type of simplicity woman. She wears her own and doesn't want to buy a new one. Thought she is inviting by Nick to attends a small party of Nick's family at Tyersall Park. She has had a plan to wears the clothes for the party. She wears a long sleeveless chocolate-colored linen dress with buttons down the front, a pair of low-heeled sandals and she uses jewelry that her mother has given her when she has got the doctorate. The analysis can be explained by the following quotation:

"Rachel decided to wear what she had been planning to wear in the first place, a long sleeveless chocolate-colored linen dress with buttons down the front, a simple cinched belt made out same of the same fabric, and a pair of lowheeled sandals. She put on a fun silver bracelet that wrapped around her wrist several times and more the only expensive piece of jewelry she owned, Mikimoto pearl studs that her mother had given her when she got her doctorate." (Kwan, 2013: 155)

Rachel Chu lives with her mother (Kerry Chu) she is a single parent. Rachel spent her childhood in California she moved around everywhere in her childhood. In her teenager, she tried to have close relationships to a boy however never success. She found a difficulty to have a close relationship to a boy because she had never known her father from she was child. The analysis can be explained by the following quotation:

"I spent my teenage years in California, but I've lived in twelve different states. We moved around quite a bit when I was younger."

"Yes, we lived the Gypsy life until my teenage years, when we settled down in California." (Kwan, 2013: 268)

"Rachel, I know it's hard for you to relate properly to Asian men, since you never knew your father." (Kwan, 2013: 90) 
From the quotation above, Rachel's family is a hard working. They move around to find a new job for livings. It is a complicated situation for a young girl like Rachel to have a close relationship to a boy. She never knew her father since her childhood. She thought that her father has pass away, she has no feeling with a boy because she has got traumatic with the marriage her parent.

\section{Social Class Influences of Middle Class Toward Rachel Chu}

Social class influences Rachel's life, especially when she has close relationship with Nick. She has social life with the upper class (Nick's family). She is bullied by the peoples from the upper class because of her simple clothes which are not from famous designer. She has got a rude reaction because she is from working class family. They said that Rachel origin is unclear, her mother is the backbone and without a father. The condition hurts Rachel very much because she never knows her father from she was child. She also doesn't get the blessing from Eleanor (her boyfriend's mother) because she doesn't come from the upper class family.

\section{Working Class}

The working class are minimally educated people who are involved in manual labor with sufficient income, the working class has relatively limited power in their workplaces.

\section{- Kerry Chu}

Kerry Chu is a single mother. She brings her child everywhere, Kerry works alone to support herself and her daughter (Rachel Chu). Kerry works as a hostess or a waitress in Chinese restaurants for the first time of her job and she gets promotion from her boss quickly. The analysis can be explained by the following quotation:

"I realize that, mom. I know it's different because you were a single mom, and you took me everywhere" Rachel mused. (Kwan, 2013: 68)

"My mom worked in Chinese restaurant."

"She usually started out as a hostess or a waitress, but she always managed to get promoted quickly." (Kwan, 2013: 268)
Kerry Chu put herself through college in America, she takes night school until she has got a college degree and works as a successful real estate agent in the Los Altos office at Polo Alto Area. She is able to finance her daughter for studying at the University in America. The analysis can be explained by the following quotation:

"My mother is a real estate agent in the Palo Alto Area." (Kwan, 2013: 232)

"My mom put herself through night school, got a college degree, and has been a successful real estate agent for many years now." (Kwan, 2013: 269)

"She put herself through college in America and is now a real estate agent. She's done well for herself and was even able to support me through my university studies," (Kwan, 2013: 337)

Kerry Chu comes from a poor family, after she has got married her mother-in-law doesn't like her because she comes from a small village. She is very lucky to get married with a rich man because of her beauty. She leaves the family even though she feels sad, because she is very happy to have got married a rich man and her dreams become true to lives in a big house and her worthy man as her husband. The analysis can be explained by the following quotation:

"My parents were devastated, but I thought all my dreams had come true. Here I was living in a big house with his rich and important parents, getting to ride in a big Nissan sedan that had white curtains on the back windows." (Kwan, 2013: 513)

"So she was very snobbish, and she never let me forget that I was just a village girl who got very, very lucky because of my looks." (Kwan, 2013: 514)

After having married and has got a daughter (Rachel Chu), she goes to America because she wants to be separated from her rude husband. She prefers to live with her uncle (Mr. Walt) who lives in California. Uncle Walt is a kind man and he understands the situation of Kerry. He takes Kerry and Rachel to America and fulfill their needs. The analysis can be explained by the following quotation: 
"A Chu cousin in California had heard about my situation, your uncle Walt and he offered to fund our way to America. $\mathrm{He}$ was the one who sponsored us," (Kwan, 2013: 521)

From the quotation above, it can be seen that Kerry Chu comes from a hard-working family. Her parents never care about social status of others, whether they are from a rich or poor family. They only want their children to concentrate on studies so their children could pass the qualified university. On the other hands, her relatives (uncle Walt) are really care of other people. He will be very pleased to help other family if they are in trouble. That's way, uncle Walt take Kerry and Rachel to America when he knew that Kerry is in difficult condition.

\section{Social Class Influences of Working Class Toward Kerry Chu}

Social class influences Kerry Chu because she comes from a working class family. She is not rich woman and comes from a small village. When she falls in love with a rich young man, she is contaminated by their habits. She becomes intoxicated by this world and has a desire to change her social status. Unfortunately, her mother-in-law doesn't like her after having married because she comes from a small village. Her mother-in-law thought that she is just looking for money. Kerry Chu has got a rude action from motherin-law. She is like a servant and her husband is an alcoholic man who likes to hit her. That's way, Kerry decides to run away and becomes a single parent. Fortunately, her relative (uncle Walt) helps her, he takes Kerry and her baby to live in America.

\section{CONCLUSION}

There are three kinds of social class as sociological problems of the important characters are found in Kevin Kwan's Crazy Reach Asians, those are: upper class, middle class and working class. In this novel, there are five important characters to be analyzed in this research, they are: Nicholas Young, Eleanor Young, Astrid Leong, Rachel Chu and Kerry Chu.

Upper class is the first kinds of social class. It can be found in the 'Young' family who had money from generations and one of the conglomerates that controls the largest shipping in the world. They are Nicholas Young and Eleanor Young. The second social class is the middle class. The middle class can be found in the character of Rachel Chu. She lives only with her mother (Kerry Chu), Rachel is a professor of Economics at NYU. She is not materialistic person and prefers to save money for living. The third social class is working class. It can be found in the character of Kerry $\mathrm{Chu}$, she is a single parent. Kerry comes from a poor family in the small village.

The social class above influence the characters in the story. Nicholas is a 'Young' family, he has to keep the name of 'Young' very well. He can't get relationship with a girl who comes from different social class. Everything is an arranged by the rule of his mother (Eleanor Young). Social class also influences Astrid Leong. After she got married, it is difficult condition for Astrid, because she can't leave her luxurious life without shopping expensive clothes and jewelry. Social class influences the character of Rachel Chu. She is bullied by upper class peoples because she wears a simple dress without famous designer. It also influences her mother (Kerry Chu).

\section{REFERENCES}

Di Yanni, R. (2001). Literature Reading Fiction, Poetry, and Drama. The McGraw-Hill Companies, Inc.

Egri, L. (1946). The Art of Dramatic Writing. Simon and Schuster.

Giddens, A., \& Griffiths, S. (2006). Sociology. Polity Press.

Griffith, K. (2006). Writing Essays about Literature. Thomson Corporation.

Jones, R. J. B. (2001). Encyclopedia of International Political Economy. Routledge.

Kenney, W. (1966). How to Analyze Fiction. Simons and Schulter Division of Gulf \& Western Corporation.

Reaske, C. R. (1976). How to Analyze Drama. Monarch Press.

Ritzer, G., \& Ryan, M. J. (2011). The Concise Encyclopedia of Sociology. Blackwell Publishing Ltd.

Sari, R. P., \& Gaho, R. (2020). Indonesian Interference in the Students' Writing of Recount Text at SMA Negeri 1 Toma. RETORIKA: Jurnal Ilmu Bahasa, 6(2).

Schaefer, R. T. (1986). Sociology. McGraw - Hill Inc.

Smelser, N. J. (1981). Sociology and Human Science. Prentice Hall.

Swingewood, A. (1972). The Sociology of 
Literature. Schocken Books.

Tyson, L. (2006). Critical Theory Today. Taylor \& Francis Group.

Wellek, R., \& Warren, A. (1956). Theory of Literature. Harcout Brace \& World, Inc. 